\title{
Antibodies to Native and Denatured Deoxyribonucleic Acid in Systemic Lupus Erythematosus *
}

\author{
Roberto Arana + and Maxime Seligmann \\ (From the Research Institute for Blood Diseases of the University of Paris, Hôpital \\ Saint-Louis, Paris, France)
}

\begin{abstract}
The relative reactivities with native and denatured DNA of 35 lupus sera were investigated by quantitative complement fixation and precipitin studies and showed great variations. The use of purified native DNA demonstrated that, in at least 22 of these 35 sera, the anti-DNA antibodies reacted with the native form, independently of denatured contaminants. Systemic lupus sera were shown to contain three main types of DNA antibodies: those reacting only with denatured DNA, those reacting to the same extent with both forms of DNA, and those reacting preferentially with native DNA. In some instances, the latter antibodies fix complement and precipitate only with native DNA but are inhibited by the denatured form. This finding points to the importance of conformation in the antigenic structure of DNA. The simultaneous occurrence of different varieties of DNA antibodies was demonstrated in several sera. Evidence was obtained that some of these human antibodies to DNA can belong to the IgM class. Thus, DNA antibodies from systemic lupus patients differ in many respects from most of the experimentally produced antibodies capable of reacting with DNA.
\end{abstract}

\section{Introduction}

The presence in the sera of some patients with systemic lupus erythematosus (SLE) of antibodies reacting with deoxyribonucleic acid (DNA) was demonstrated $10 \mathrm{yr}$ ago (1-4). The early studies on these antibodies $(5,6)$ were performed with native DNA. Subsequently it was shown that these antibodies still reacted with DNA that was previously denatured or degraded by various procedures (7). In further studies, Stollar and Levine reported that all but one of their DNAreactive SLE sera reacted exclusively, or more

* Received for publication 15 March 1967 and in revised form 5 July 1967.

Aided (in part) by a grant from the French National Institute for Medical Research (No. CR. 66. 237).

$\ddagger$ Fellow of the National Council for Scientific Investigations (Argentina) and of the World Health Organization. Dr. Arana's present address is C.E.M.I.C. Bustamante 2560, Buenos Aires.

Address requests for reprints to Dr. Maxime Seligmann, Research Institute for Blood Diseases, Hôpital Saint-Louis, Paris 10e, France. effectively, with thermally denatured DNA $(8,9)$. Since the first unequivocal demonstration of experimentally induced antibodies capable of reacting with DNA (10), most of the experimentally produced antibodies, whatever the immunizing material, were shown to react only with denatured DNA. Therefore, in recent years, most reports in this field have been devoted to immunological reactions with denatured DNA.

In the present work, a study of the relative reactivities with native and denatured DNA of a series of SLE sera was carried out. The purpose of the experiments was to determine: $(a)$ to what extent the previously observed reactions with native DNA were due to a denatured contaminant; (b) whether some lupus antibodies reacted preferentially or exclusively with native DNA; and $(c)$ whether different anti-DNA antibodies with various specificities could be demonstrated in a single lupus serum. In addition, evidence was obtained that anti-DNA antibodies from SLE patients can belong to the IgM class. 


\section{Methods}

SLE sera. 35 sera from patients with active SLE were selected because of their positive reactions with native and/or denatured DNA by a routine complement fixation test. Some of these sera had been stored at $-20^{\circ} \mathrm{C}$ for several months.

Nucleic acids. Highly polymerized calf thymus DNA was obtained from Worthington Biochemical Corporation (Freehold, N. J.) ; a single batch (No. 652) was used for all experiments. Samples of Escherichia (E.) coli and T 7 phage DNA were kindly supplied by Doctors F. Gros and L. J. P. Richardson. C 2 phage DNA was a gift of Dr. R. Van Rapenbusch. The DNA concentrations were estimated by absorption at $260 \mathrm{~m} \mu$ in a Beckman model D.U. spectrophotometer (Beckman Instruments Inc., Fullerton, Calif.). Yeast ribonucleic acid was obtained from Worthington Biochemical Corporation and $E$. coli RNA was a gift of Dr. Larsen. The preparations of calf thymus purified native DNA were obtained by chromatography on Kieselguhr impregnated with methylated albumin, according to the method of Mandel and Hershey (11). The peak corresponding to $0.8 \mathrm{M}$ $\mathrm{NaCl}$ was dialyzed against $0.15 \mathrm{M} \mathrm{NaCl}$.

For complement fixation tests, DNA preparations were denatured at concentrations of $1 \mu \mathrm{g} / \mathrm{ml}$ in complement fixation buffer by boiling for $10 \mathrm{~min}$ at $100^{\circ} \mathrm{C}$ followed by rapid cooling in an iced water bath. Further dilutions were made in the chilled complement fixation buffer.

For precipitin experiments, DNA was denatured at concentrations varying between 50 and $200 \mu \mathrm{g} / \mathrm{ml}$ in Tris buffer, $\mathrm{pH} 8.2,0.05 \mathrm{M} \mathrm{NaCl}$ with or without $1 \%$ formaldehyde. Subsequent dilutions were made in Tris buffer, $\mathrm{pH} 8.2,0.15 \mathrm{M} \mathrm{NaCl}$. In order to assess the absence of double stranded DNA in these preparations, a ring-test was performed before use with a serum reacting only with native DNA (10466, see below). For gel diffusion tests, DNA was submitted to sonic oscillation for $10 \mathrm{~min}$ at $960 \mathrm{KHz}$ (acoustic power, $120 \mathrm{w}$ ) under the conditions described in reference 12 , under hydrogen atmosphere. The molecular weight of the sonicated fragments was 300,000 as determined by sedimentation coefficients in ultracentrifugal analysis.

The renaturation experiments were performed as follows: $\mathrm{T} 7$ phage $\mathrm{DNA}$ was dissolved in $0.015 \mathrm{M} \mathrm{NaCl}$ at $40 \mu \mathrm{g} / \mathrm{ml}$. Four samples were prepared as follows. (a) Native DNA was prepared in complement fixation buffer. (b) Native DNA was diluted in a Tris buffer, $\mathrm{pH} 7.4$, $1.4 \mathrm{M} \mathrm{NaCl}$ to a final concentration of $20 \mu \mathrm{g} / \mathrm{ml}$ and $0.7 \mathrm{M}$ $\mathrm{NaCl}$; this solution (NAT. $56^{\circ} \mathrm{C}$ sample) was incubated at $56^{\circ} \mathrm{C}$ in the same way as the sample to be renatured was; $(c)$ denatured DNA was prepared by boiling for 15 min at $100^{\circ} \mathrm{C}$, quickly cooled, and diluted in chilled complement fixation buffer. (d) Renatured DNA was prepared as follows: after boiling for $15 \mathrm{~min}$ at $100^{\circ} \mathrm{C}$, DNA was diluted in a Tris buffer, $\mathrm{pH} 7.4$, preheated to $56^{\circ} \mathrm{C}$, to a final concentration of $20 \mu \mathrm{g} / \mathrm{ml}$ and $0.7 \mathrm{M} \mathrm{NaCl}$; this preparation was incubated at $56^{\circ} \mathrm{C}$ for $6 \mathrm{hr}$. At time zero and then at regular intervals during incubation, $0.1 \mathrm{ml}$ samples were taken and transferred in $40 \mathrm{ml}$ of chilled complement fixation buffer (final DNA concentration, $0.05 \mu \mathrm{g} / \mathrm{ml}$ ).

Deoxyribonuclease (DNAse) digests were obtained by incubation at $37^{\circ} \mathrm{C}$ of $30 \mu \mathrm{g} / \mathrm{ml}$ of native calf thymus DNA with $0.03 \mu \mathrm{g} / \mathrm{ml}$ of pancreatic DNAse twice crystallized, in phosphate buffer, $\mathrm{pH} 6.8,0.01$ mole/liter in the presence of $0.011 \mathrm{M} \mathrm{MgCl}_{2}$. Digestion was complete after $24 \mathrm{hr}$ (as determined by measurements of release of acid soluble material at $260 \mathrm{~m} \mu$ ). The enzyme was destroyed by boiling the end products for $10 \mathrm{~min}$ at $100^{\circ} \mathrm{C}$, followed by rapid cooling.

Purified antibodies. Purified DNA antibodies were obtained by digestion of specific precipitates by DNAse, as described previously (5).

Complement fixation. The quantitative microcomplement fixation technique, as described by Wasserman and Levine (13), was used, in a total volume of $3.5 \mathrm{ml}$ with a Tris/ $\mathrm{HCl}$ buffer, $\mathrm{pH} 7.4$, containing $0.14 \mathrm{M} \mathrm{NaCl}, \mathrm{Mg}^{++}$ $5 \times 10^{-4}$ mole/liter and $\mathrm{Ca}^{++} 1.5 \times 10^{-4}$ mole/liter. Gelatine was added to a final concentration of $0.1 \%$. All samples were diluted in this buffer, except DNA before denaturation, which was dissolved in buffer without gelatine. Inhibition experiments were performed under conditions similar to those of Wasserman and Levine, utilizing concentrations of antiserum and antigen which gave a maximal percentage of complement fixation. Experimental procedures were carried out in duplicate, and controls for anticomplementary activity of serum, antigen, and inhibitors were always included. The concentrations of serum, antigen, or inhibitors stated in the present study are not the final concentrations in the reaction mixtures, but the concentrations added to the test tubes.

All sera were tested against calf thymus DNA; some were also tested against DNA from other sources. All comparative experiments were performed simultaneously. Because of anticomplementary activity of our denatured DNA preparations, the highest concentrations used were $0.4-0.8 \mu \mathrm{g} / \mathrm{ml}$.

Quantitative precipitin curves. Different concentrations of antigen in $0.2 \mathrm{ml}$ of Tris buffer, $\mathrm{pH} 8.2,0.15 \mathrm{M} \mathrm{NaCl}$ were added to aliquots of $0.2 \mathrm{ml}$ of serum. The reaction mixtures were incubated at $37^{\circ} \mathrm{C}$ for $1 \mathrm{hr}$ and at $4^{\circ} \mathrm{C}$ for 5 days. The precipitates were washed three times in Tris buffer, $\mathrm{pH} 8.2$, and finally dissolved in $0.2 \mathrm{ml}$ of $0.1 \mathrm{~N}$ $\mathrm{NaOH}$. The optical densities were measured at $280 \mathrm{~m} \mu$ and the figures were not corrected for antigen values.

For inhibition experiments $0.1 \mathrm{ml}$ of inhibitor at different concentrations was added to aliquots of $0.2 \mathrm{ml}$ of serum. The tubes were incubated for $1 \mathrm{hr}$ at $37^{\circ} \mathrm{C}$, at which time $0.1 \mathrm{ml}$ of antigen was added. The mixture was incubated at $37^{\circ} \mathrm{C}$ for $1 \mathrm{hr}$ and at $4^{\circ} \mathrm{C}$ for 5 days. The amount of antigen added was chosen in order to be in the beginning of the equivalence zone. The control tubes included serum alone, serum and native DNA (with and without formaldehyde), and serum with the highest concentration of inhibitor.

Double diffusion tests. Tests were performed in $0.6 \%$ agarose in phosphate buffer, $\mathrm{pH} 7.2,0.15 \mathrm{M} \mathrm{NaCl}$. The determination of the class of immunoglobulins of puri- 


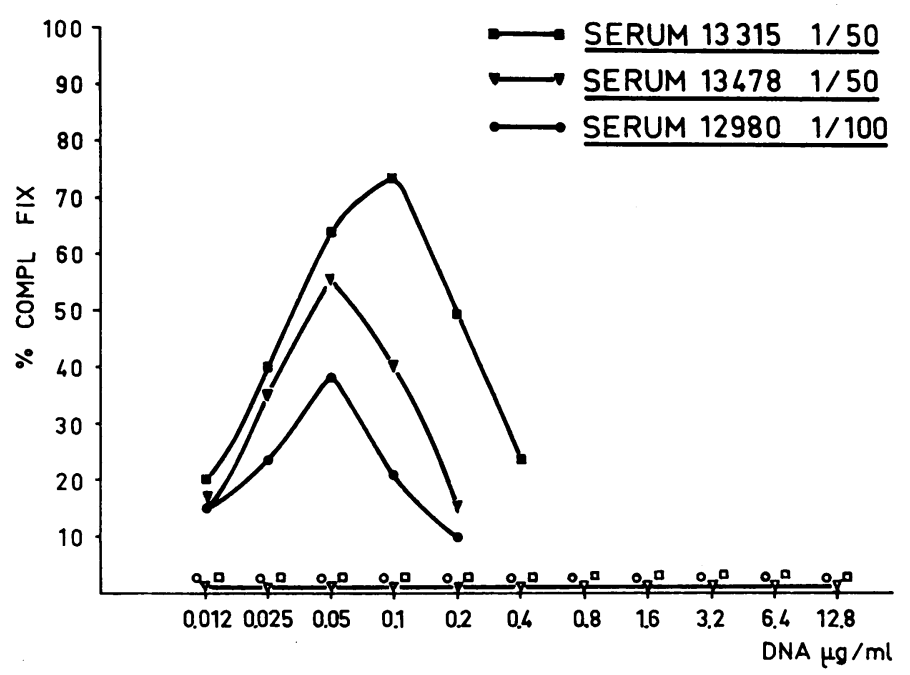

Fig. 1. Complement fixation by three SLE sera. Open symbols, native DNA; closed symbols, denatured DNA.

fied antibodies was performed in $1.5 \%$ agar in buffered saline, $\mathrm{pH} 7.2$, using rabbit antisera specific for $\boldsymbol{\gamma}-, \boldsymbol{\mu}$-, and $\alpha$-chains of immunoglobulins.

\section{Results}

Quantitative complement fixation and inhibition studies. The 34 sera tested by quantitative complement fixation showed great variations in the relative reactivities with native and denatured DNA.

Some sera react exclusively with denatured DNA. Fig. 1 shows an example of three different sera reacting in this way. In some instances, sera giving a maximal complement fixation with 0.05
$0.1 \mu \mathrm{g} / \mathrm{ml}$ of denatured DNA fixed variable amounts of complement when tested with high concentrations of native DNA. As observed in Fig. $2 a$, this latter reaction did not occur when a preparation of purified native DNA was used as antigen. The reaction could therefore be ascribed to denatured DNA contaminating the native preparation. Altogether, 10 of the 34 sera were demonstrated to react only with denatured DNA. Furthermore, in quantitative inhibition experiments, purified native DNA, up to $20 \mu \mathrm{g} / \mathrm{ml}$, did not interfere with the complement fixation reaction of those sera with denatured DNA.

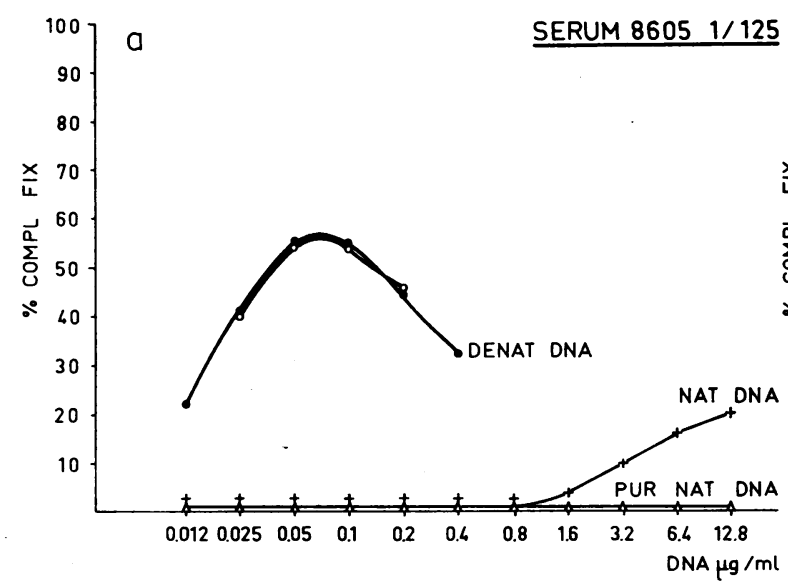

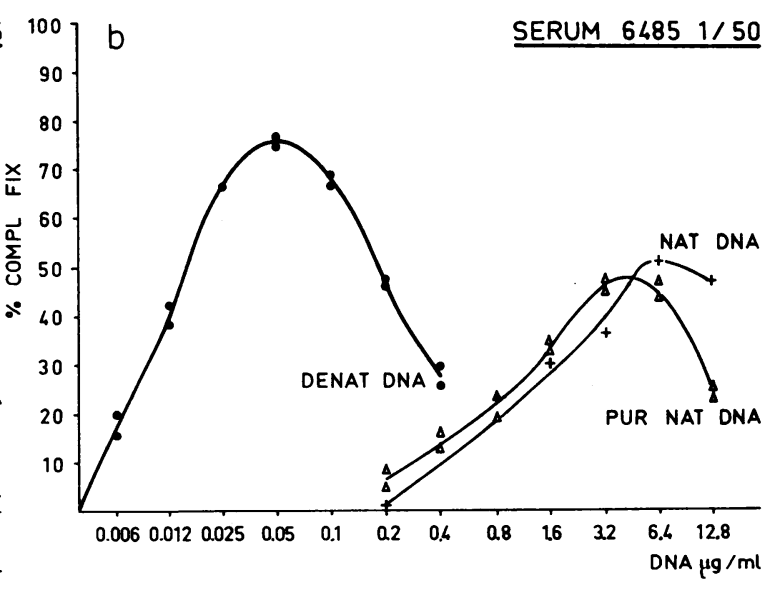

Fig. 2. Complement fixation curves performed simultaneously. (a) Serum reacting with a denatured contaminant of the native preparation. $\mathrm{O}-\mathrm{O}$, complement fixation with denatured DNA in the presence of $20 \mu \mathrm{g} / \mathrm{ml}$ of purified native DNA. (b) Serum reacting with native and purified native DNA at concentrations 100 times higher than that of denatured DNA. 


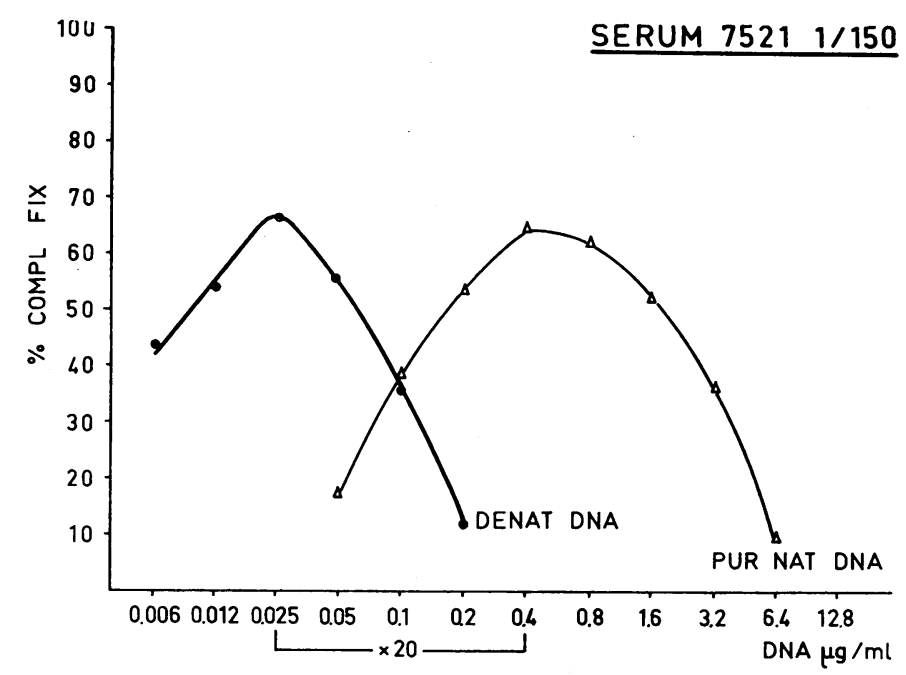

Fig. 3. Complement fixation OF ONE SERUM REACTING With PURIFIED NATIVE DNA AT A CONCENTRATION 20 TIMES GREATER THAN THAT REQUIRED FOR DENATURED DNA.

For serum 6485 (illustrated in Fig. $2 b$ ), the hypothesis of a small amount of single chain denatured DNA contaminating the native preparation could be excluded, even though a concentration of native DNA 100 times greater than that of denatured DNA was required for reactivity: the complement fixation curve with purified native DNA is similar to that of native DNA, except in the antigen excess zone. Two other sera reacted with concentrations of native or purified native DNA 20 times greater than those of denatured DNA, giving the same maximal complement fixation (Fig. 3). Cross-inhibition experi- ments could not be performed because of lack of serum. For the same reason, three other sera reacting with a concentration of native. DNA 50 times greater than that of denatured DNA could not be studied with purified native DNA.

Four sera showed a reaction with a peak for similar concentrations of native and denatured DNA, but denatured DNA fixed more complement. The curves of two such sera are shown in Fig. 4. Whereas, for serum 3258 , no complement fixation with denatured DNA occurred in the presence of $6.4 \mu \mathrm{g} / \mathrm{ml}$ of purified native DNA, inhibition by purified native DNA leveled off at
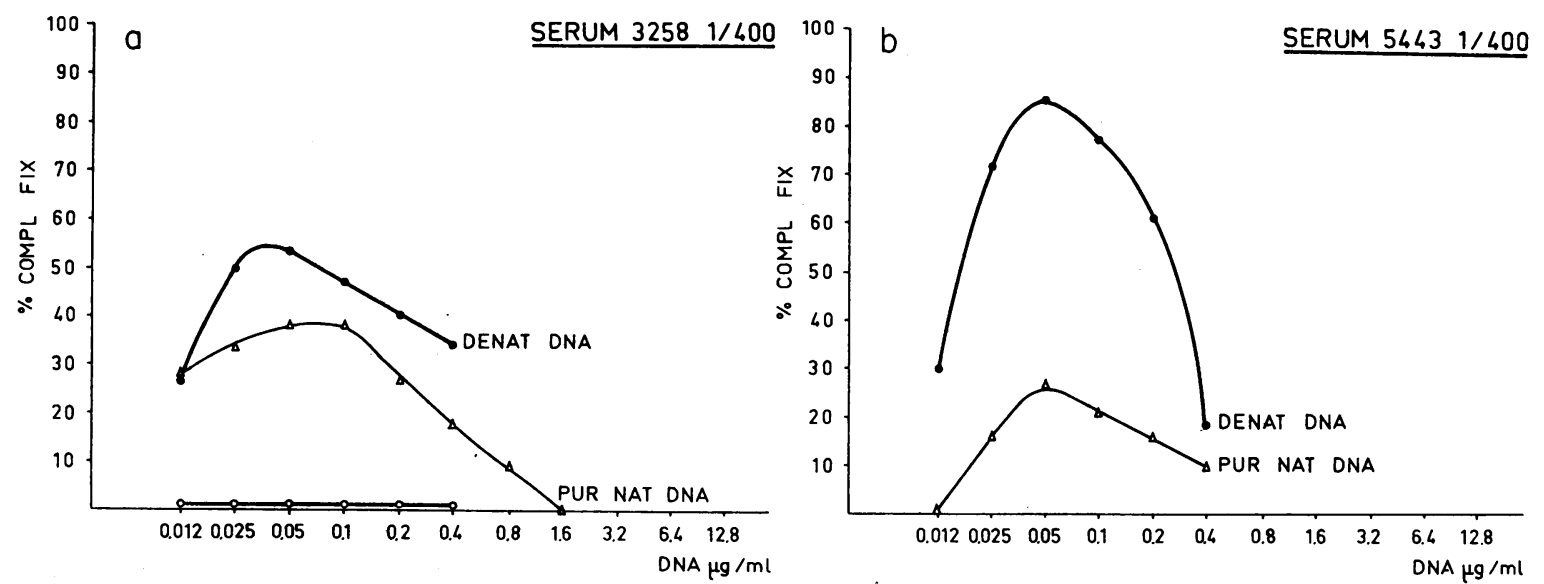

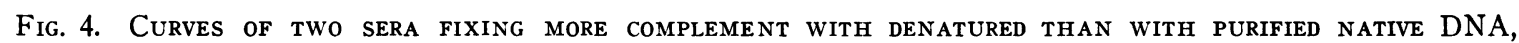
With PEAK FiXation at similar antigen concentrations. $\bigcirc-\bigcirc$, complement fixation with denatured DNA in the presence of $6.4 \mu \mathrm{g} / \mathrm{ml}$ of purified native DNA. 

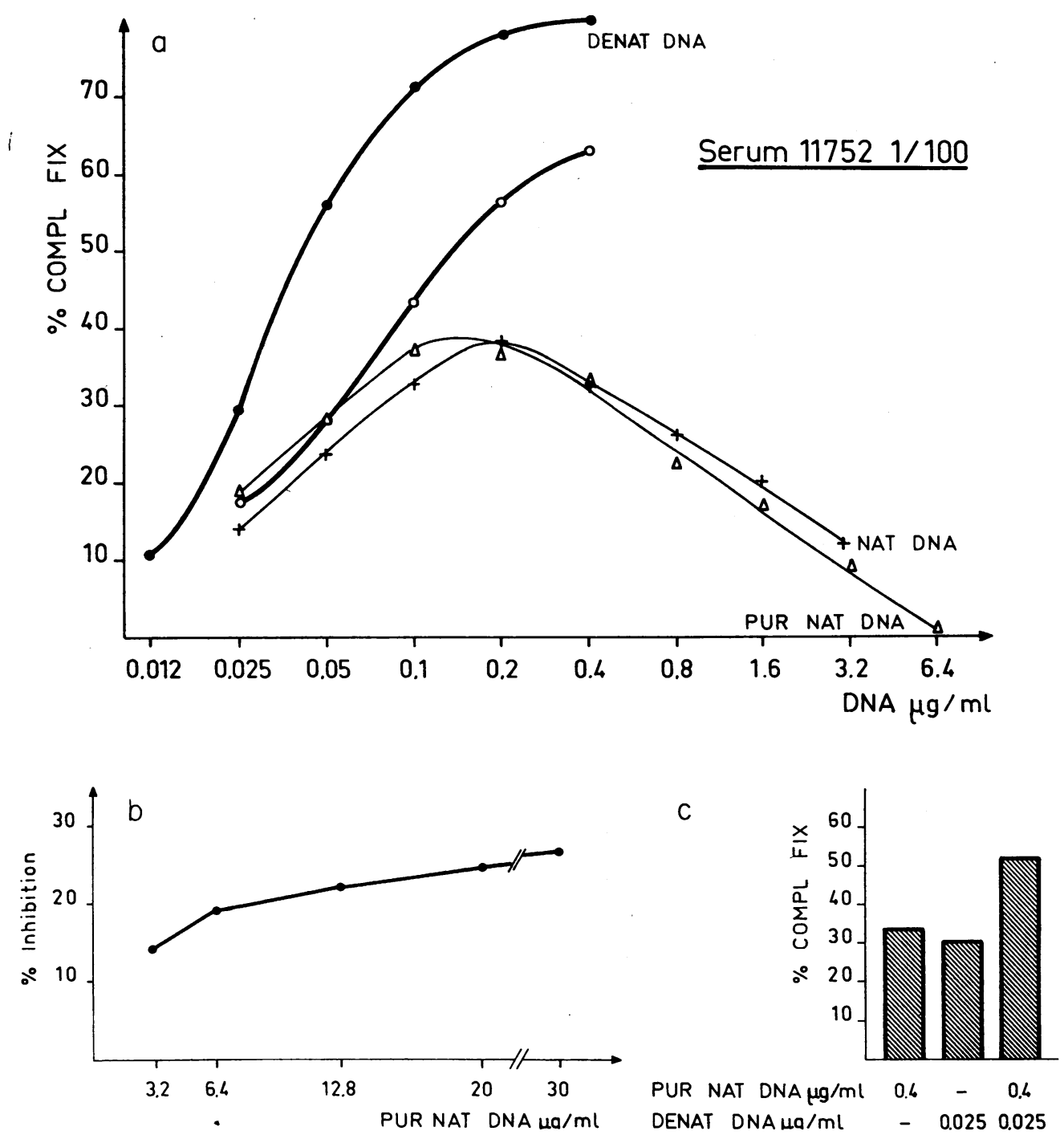

Fig. 5. Complement fixation Reactions of SERUm 11752 with DNA. (a) Note the difference in complement fixation levels with denatured and native or purified native DNA. $\bigcirc-O$, complement fixation with denatured DNA, in the presence of $6.4 \mu \mathrm{g} / \mathrm{ml}$ of purified native DNA. (b) Inhibition by purified native DNA of complement fixation with $0.4 \mu \mathrm{g}$ of denatured DNA. (c) Addition experiment (see text).

$65 \%$ for serum 5443 (not shown in Fig. 4). Although serum 11752 gave an analogous reaction pattern (Fig. $5 a$ ), $30 \mu \mathrm{g} / \mathrm{ml}$ of purified native DNA was unable to inhibit more than $28 \%$ of the reaction with denatured DNA (Fig. $5 b$ ). This weak inhibition suggested that we were dealing with different kinds of antibodies. In order to confirm this hypothesis, the following experiment was performed: the addition to a fixed amount of antibody of $0.4 \mu \mathrm{g} / \mathrm{ml}$ of purified native DNA (in slight antigen excess) and $0.025 \mu \mathrm{g} / \mathrm{ml}$ of denatured DNA (in large antibody excess) resulted in a definite increase of the complement fixation (Fig. $5 c$ ).

Another type of pattern, illustrated in Fig. 6, is defined by similar complement fixation curves with native (or purified native) and denatured DNA. This has been observed for seven of our sera. Some of them give maximal complement fixation with concentrations of DNA of 0.05-0.2 $\mu \mathrm{g} / \mathrm{ml}$, while others give maximal fixation with concentrations of DNA of $0.8-1.6 \mu \mathrm{g} / \mathrm{ml}$. In all 

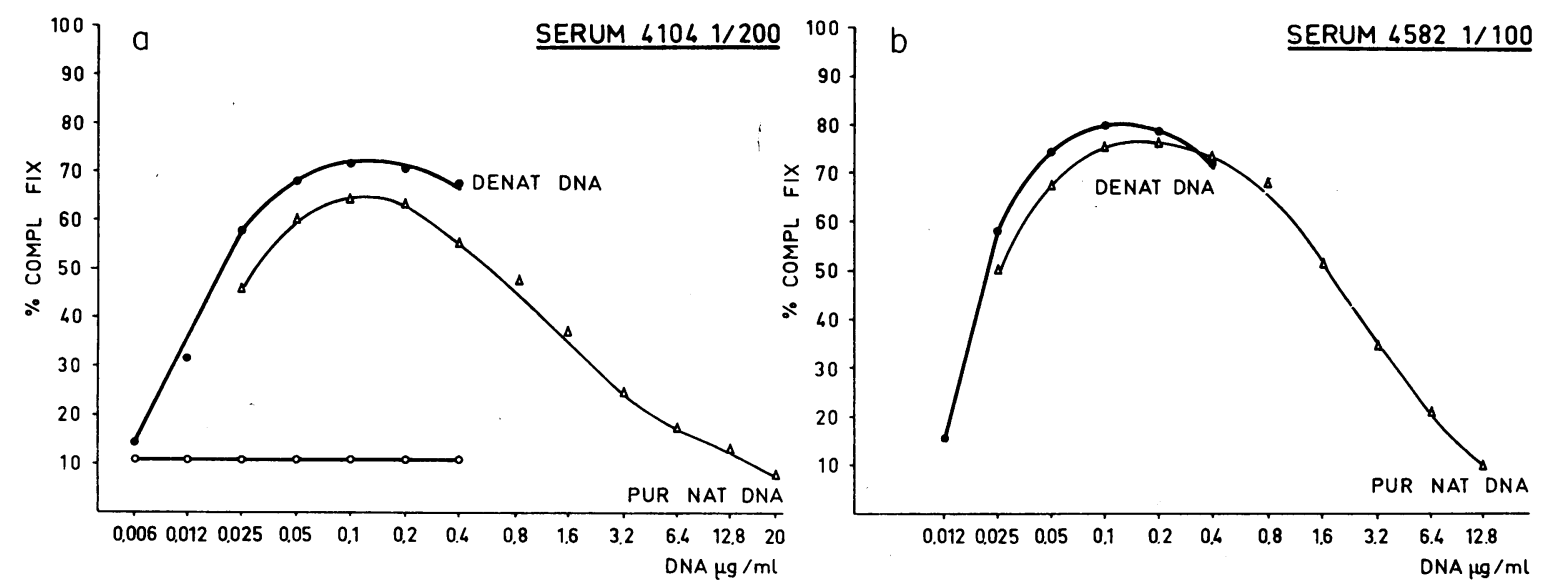

Fig. 6. Complement fixation by two sera Reacting to the same extent with purified Native ANd denaTURED DNA. $\bigcirc-O$, complement fixation with denatured DNA in the presence of $20 \mu \mathrm{g} / \mathrm{ml}$ of purified native DNA.

these instances, purified native DNA in extreme antigen excess was an effective inhibitor of the reaction with denatured DNA. These antibodies thus detect the same antigenic determinant(s) in both native and denatured DNA.

Six sera react more effectively with native than with denatured DNA. For example, with serum 8994 giving this type of pattern (Fig. $7 a$ ), when using identical concentrations of purified native and denatured DNA, the amount of complement fixed in the antibody excess zone is greater with the native form. The difference in reactivity between native and denatured DNA is more striking with $T 7$ phage DNA (Fig. $7 b$ ).

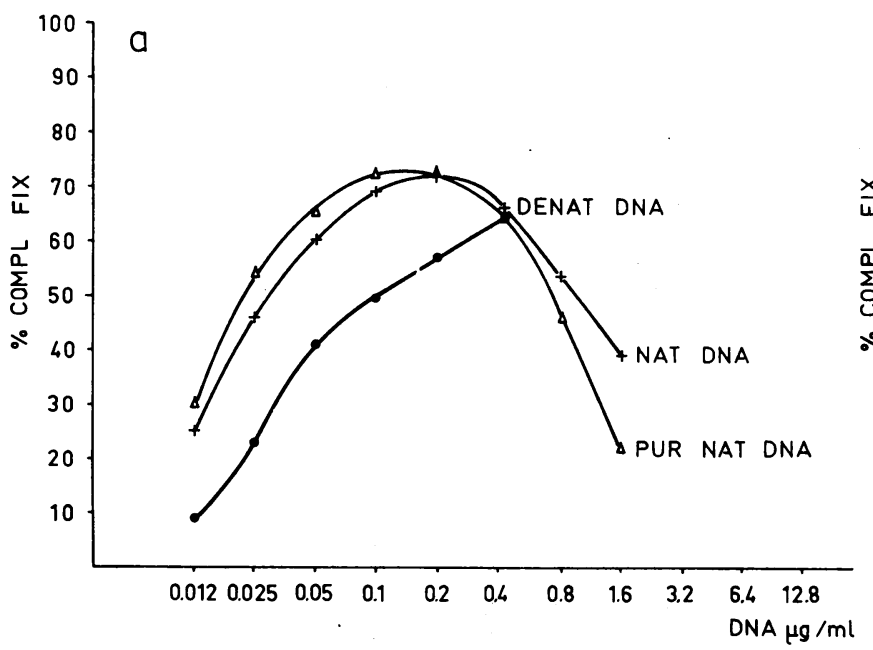

Finally, serum 10466 reacts strongly with native DNA, although denatured DNA shows little if any reaction at concentrations tested. Fig. 8 illustrates the complement fixation curves with four DNA of different sources.

Eight sera were tested with native and denatured RNA (yeast and E. coli). They include three sera reacting only with denatured DNA, three reacting to the same extent with native and denatured DNA, and two reacting preferentially with native DNA. Complement fixation experiments were negative at all concentrations, and no inhibition of the reaction with native and/or denatured DNA was observed.

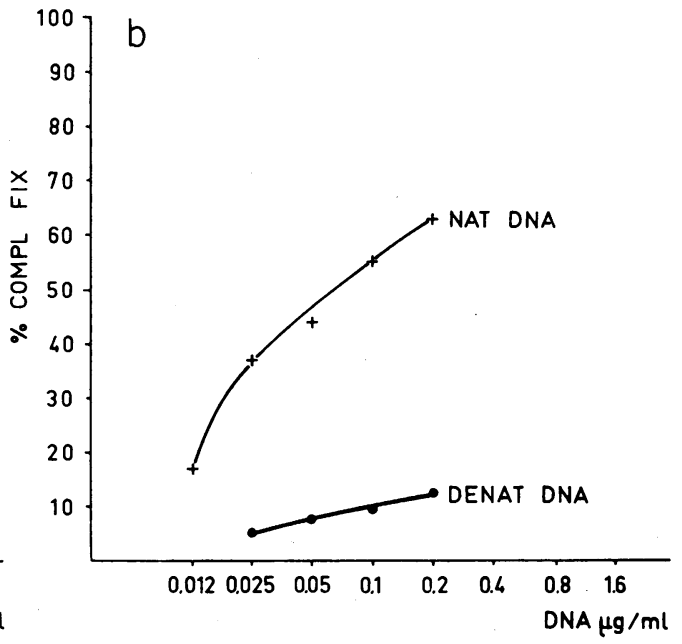

Fig. 7. Serum 8994 (1/50). Complement fixation with: (a) Calf thymus DNA; $(b)$ T 7 phage DNA. 


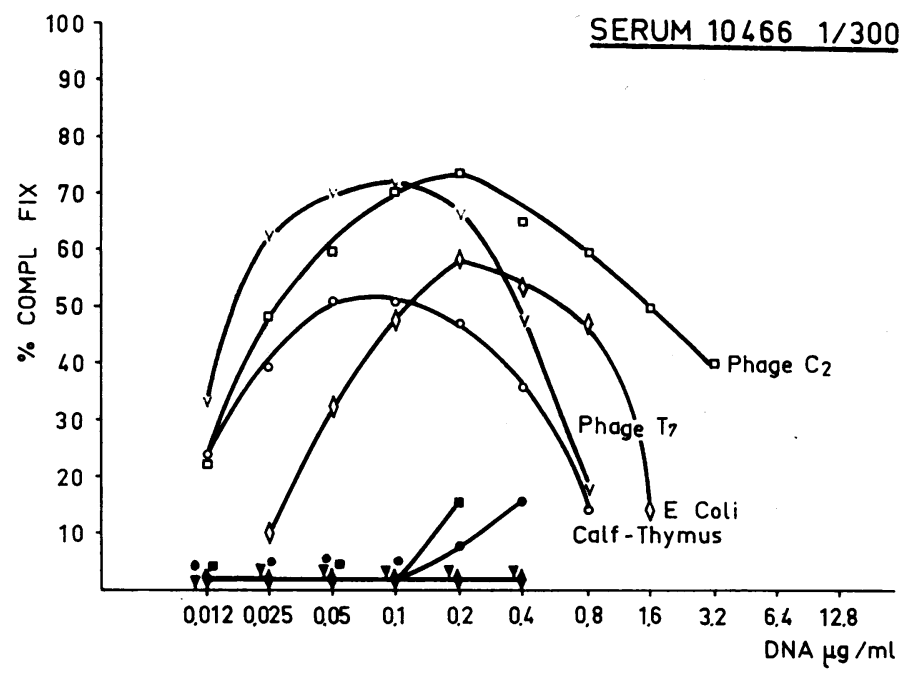

Fig. 8. Complement fixation with FOUR DNA FROM DifFERENT SOURCES. Open symbols, native DNA; closed symbols, denatured DNA.

Inhibition studies with $3 \mu \mathrm{g} / \mathrm{ml}$ of DNAse digest were performed with a limited number of sera. The four tested sera which reacted only with denatured DNA showed between 50 and $70 \%$ inhibition. One serum reacting more effectively with denatured than native DNA was weakly inhibited. On the contrary, no inhibition occurred for three sera reacting to the same extent with native and denatured DNA, two reacting preferentially with native DNA, and the one reacting only with native DNA.

Renaturation experiments. In order to show the different specificities of antibodies, the kinetics of renaturation of $\mathrm{T} 7$ phage DNA have been fol-

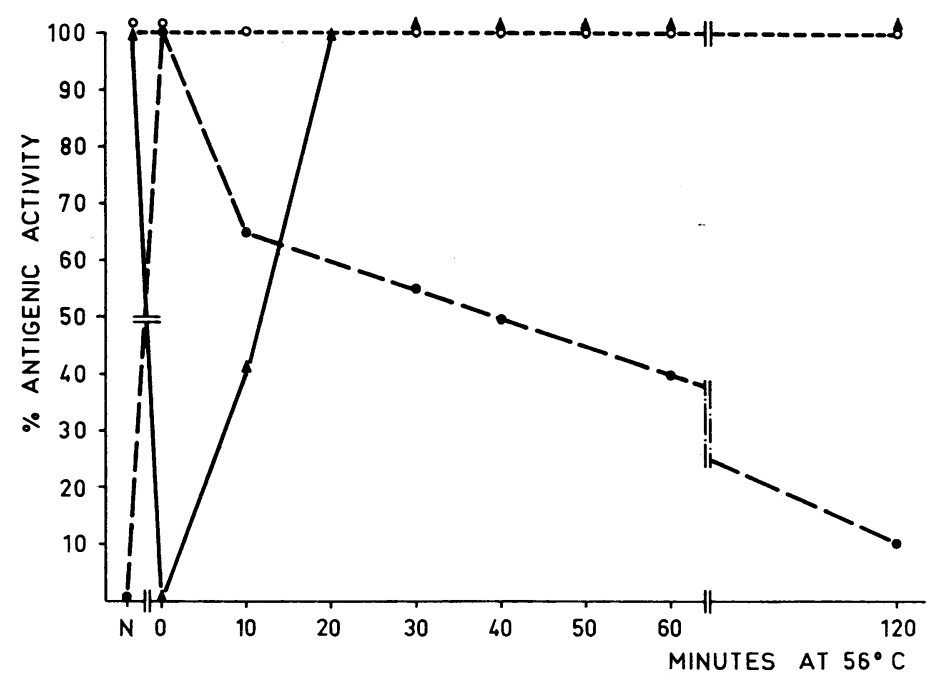

Fig. 9. T 7 Phage DNA Renaturation, AS DETERmined by COMPLEMENT FIXATION WITH THREE DIFFERENT SERA CONTAINING ANTIBodies TO: $\Delta-\Delta$, NATIVE DNA (10466); $-0-0$, DENATURED DNA (13315); AND O- - O, COMMON ANTIGENIC DETERMINANTS TO NATIVE AND DENATURED DNA (4582). 100\% antigenic activity was determined, with the sample before denaturation $(N)$ for serum 10466 , with the zero sample $(O)$ for serum 13315, and with both for serum 4582. 

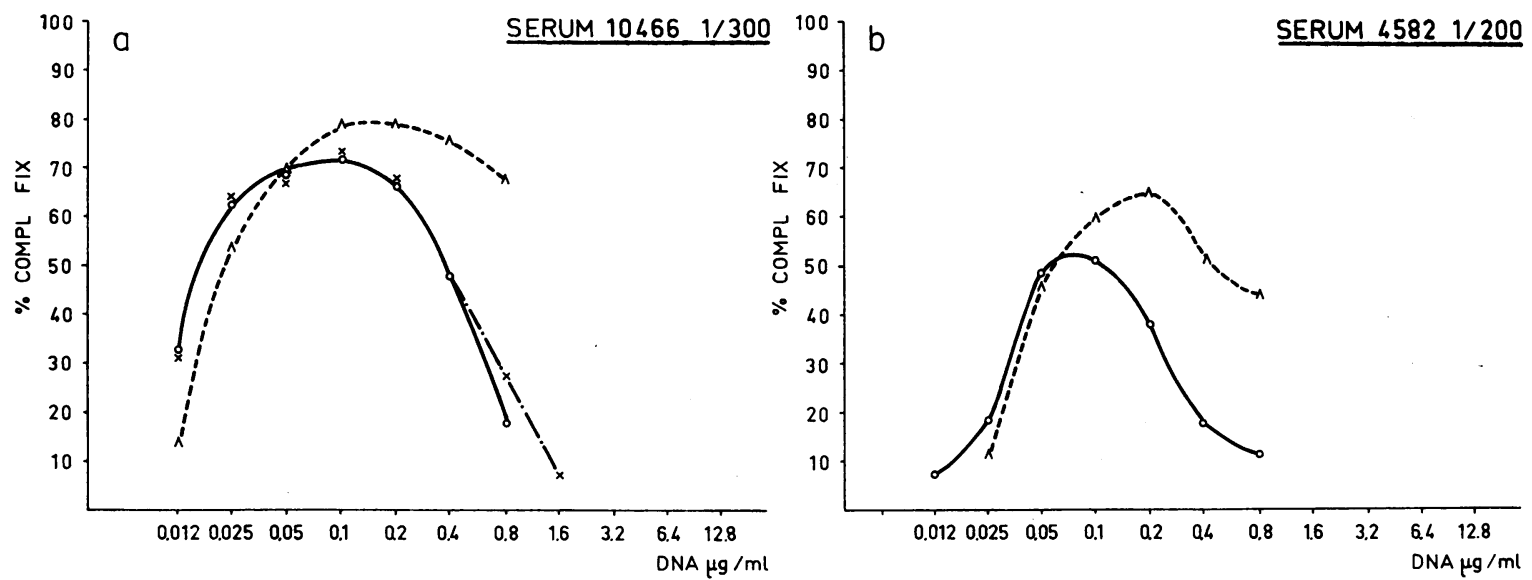

Fig. 10. Complement fixation by antibodies to NATive (a) AND to common determinants IN NATIVE AND DENatured DNA $(b)$ with T 7 phage DNA: $\bigcirc-O$, Native; $\times-\cdots \times$, Native $56^{\circ}, \wedge---\wedge$, Renatured. Note that there is no difference between native and native $56^{\circ}$ curves $(a)$. Note also the shift to the right and the increment in complement fixation with renatured DNA ( $a$ and $b)$.

lowed with three selected sera. The results are shown in Fig. 9. Serum 10466, reacting only with native DNA, shows maximal reactivity with the sample before denaturation. No reaction occurs with the sample corresponding to the beginning of incubation (zero time). 10 min later, $40 \%$ of the antigenic activity is recovered and $100 \%$ after $20 \mathrm{~min}$ of incubation. On the contrary, serum 13315 reacting only with denatured DNA shows maximal activity with the zero sample. After $10 \mathrm{~min}$ of incubation $35 \%$ of the antigenic activity is lost ; then it slowly decreases and, with the $3 \mathrm{hr}$ sample, no more reaction is detected. Serum 4582, reacting to the same extent with native and denatured DNA, does not show

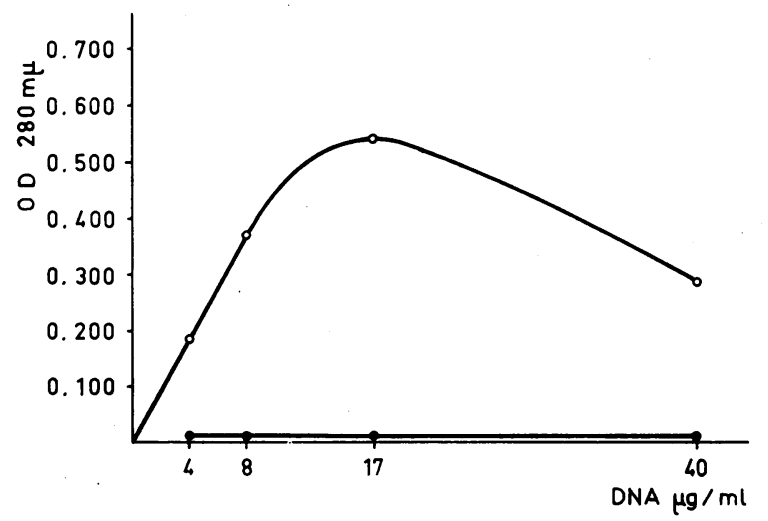

Fig. 11. QUantitative PRECipitin CURVE OF SERUM 10466 with Calf thymus DNA: $\bigcirc-0$, Native; -—, Denatured. any change in the antigenic activity upon renaturation.

Quantitative studies have been performed also with native, denatured, and renatured DNA, and with the "NAT. 56" sample (see Methods). Serum 10466 (Fig. $10 a$ ) gives identical reactions with native and NAT. $56^{\circ}$ samples. No reaction is observed with denatured DNA. With renatured DNA, there is a shift to the right of the equivalence zone, with a parodoxical increase in the amount of complement fixed in the equivalence and antigen excess zone. This peculiar reactivity of renatured DNA was also observed with serum 4582, which reacts to the same extent with native and denatured DNA (Fig. 10 b) whilst serum 13315 , reacting only with denatured DNA, did not fix complement with the same preparation. Therefore, the shift of the curves is presumably not due to the presence of single strand areas, and the increase of the amount of complement fixed might reflect conformational changes in the renatured state.

Quantitative precipitin tests. Because of the anticomplementary behavior of our denatured DNA preparations inhibition of complement fixation could not be performed for serum 10466 which reacted only with native DNA. For inhibition studies, this serum was tested with native DNA by quantitative precipitin analysis. Fig. 11 shows the precipitin curve with native DNA. The same figures were obtained with native DNA 
in the presence of formaldehyde. DNA denatured in the presence of $1 \%$ formaldehyde does not precipitate, up to concentrations of $40 \mu \mathrm{g} / \mathrm{ml}$. However, this denatured DNA was a potent inhibitor of the precipitin reaction with native DNA, since $50 \%$ inhibition was obtained with $30 \mu \mathrm{g} / \mathrm{ml}$ and $100 \%$ inhibition with $50 \mu \mathrm{g} / \mathrm{ml}$.

Similar results, both for precipitin and inhibition tests, have been observed with another serum which could not be studied in complement fixation tests because of its strong anticomplementary activity.

Antibodies in double diffusion tests. Those sera which were available have been systematically studied with various concentrations of native and denatured sonically treated DNA. Different reaction patterns have been observed.

Some sera precipitate only with the native form. However, in some instances (Fig. 12), the inhibition by denatured DNA of the precipitin reaction with native DNA is readily seen, because of the shortening of the line next to the well containing a sufficient concentration of denatured DNA. Inversely, some other sera react only with denatured DNA (Fig. 13A). In other instances, lupus sera give an identical reaction with native and denatured DNA, with complete fusion of the lines (Fig. 13B). Absorption of these sera with denatured DNA abolished the reaction with native

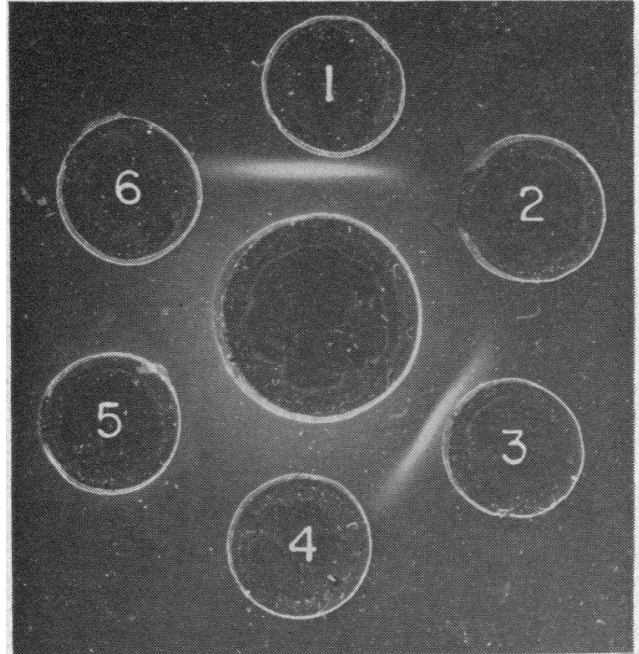

Fig. 12. Precipitin Reaction only with Native DNA AND INHIBITORY EFFECT OF DENATURED DNA. Central well: serum 13378 ; 1) native, $50 \mu \mathrm{g} / \mathrm{ml}$; 2) denatured, $50 \mu \mathrm{g} / \mathrm{ml}$; 3) native, $25 \mu \mathrm{g} / \mathrm{ml}$; 4) saline ; 5) denatured, $200 \mu \mathrm{g} / \mathrm{ml}$; 6) denatured, $10 \mu \mathrm{g} / \mathrm{ml}$.

DNA, and vice versa. In most of these cases, the precipitin line with denatured DNA was weaker than with native DNA and, in some instances, DNA denatured in the presence of formaldehyde was not able to form a precipitin line, although it gave a complement fixation curve similar to that of native DNA. Another pattern (Fig. 13C) is defined by a spur of the native
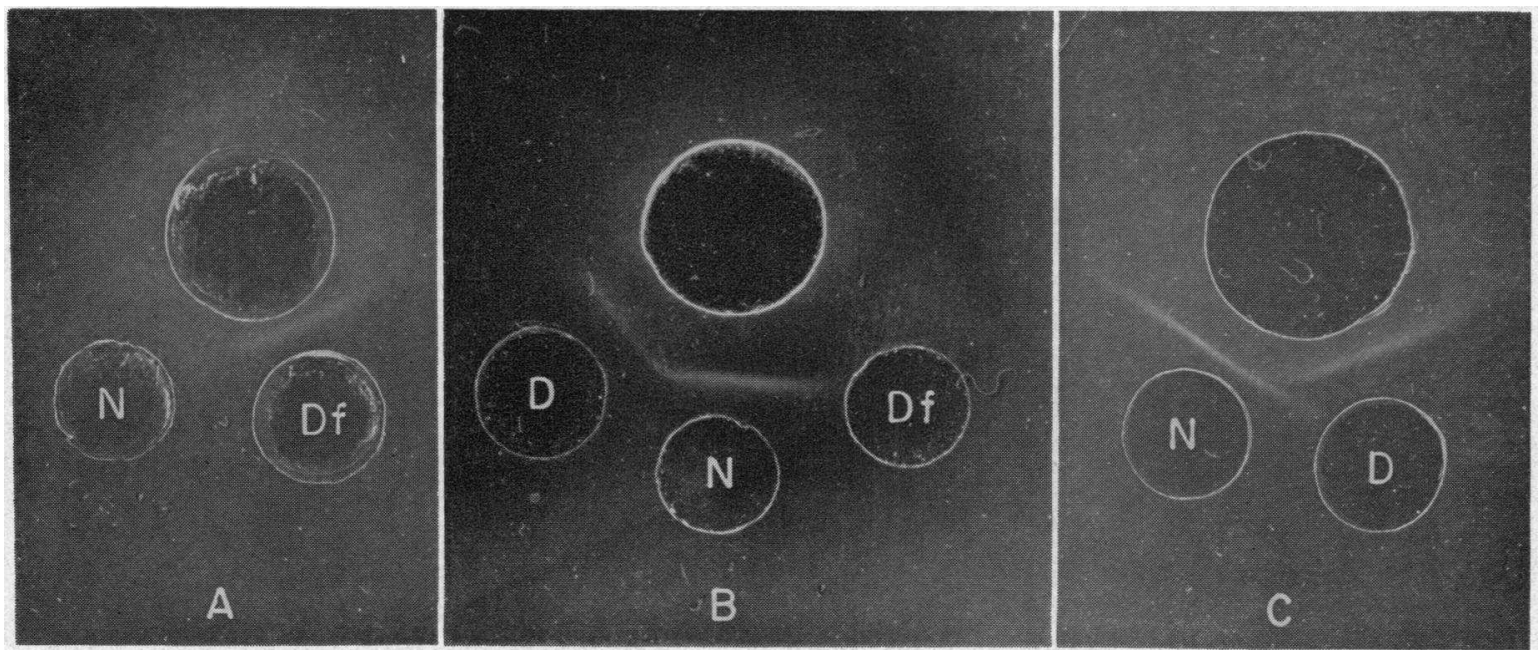

Fig. 13. (A): Precipitin reaction only with denatured DNA. Upper well: serum 12980; left well: native; right well : denatured in the presence of formaldehyde. (B) Reaction of identity. Upper well: serum 4582; left well: denatured $15 \mu \mathrm{g} / \mathrm{ml}$; bottom well : native $15 \mu \mathrm{g} / \mathrm{ml}$; right well: denatured in the presence of formaldehyde, $15 \mu \mathrm{g} / \mathrm{ml}$. (C) Reaction of partial identity. Upper well : serum 6969; left well : native; right well : denatured. 

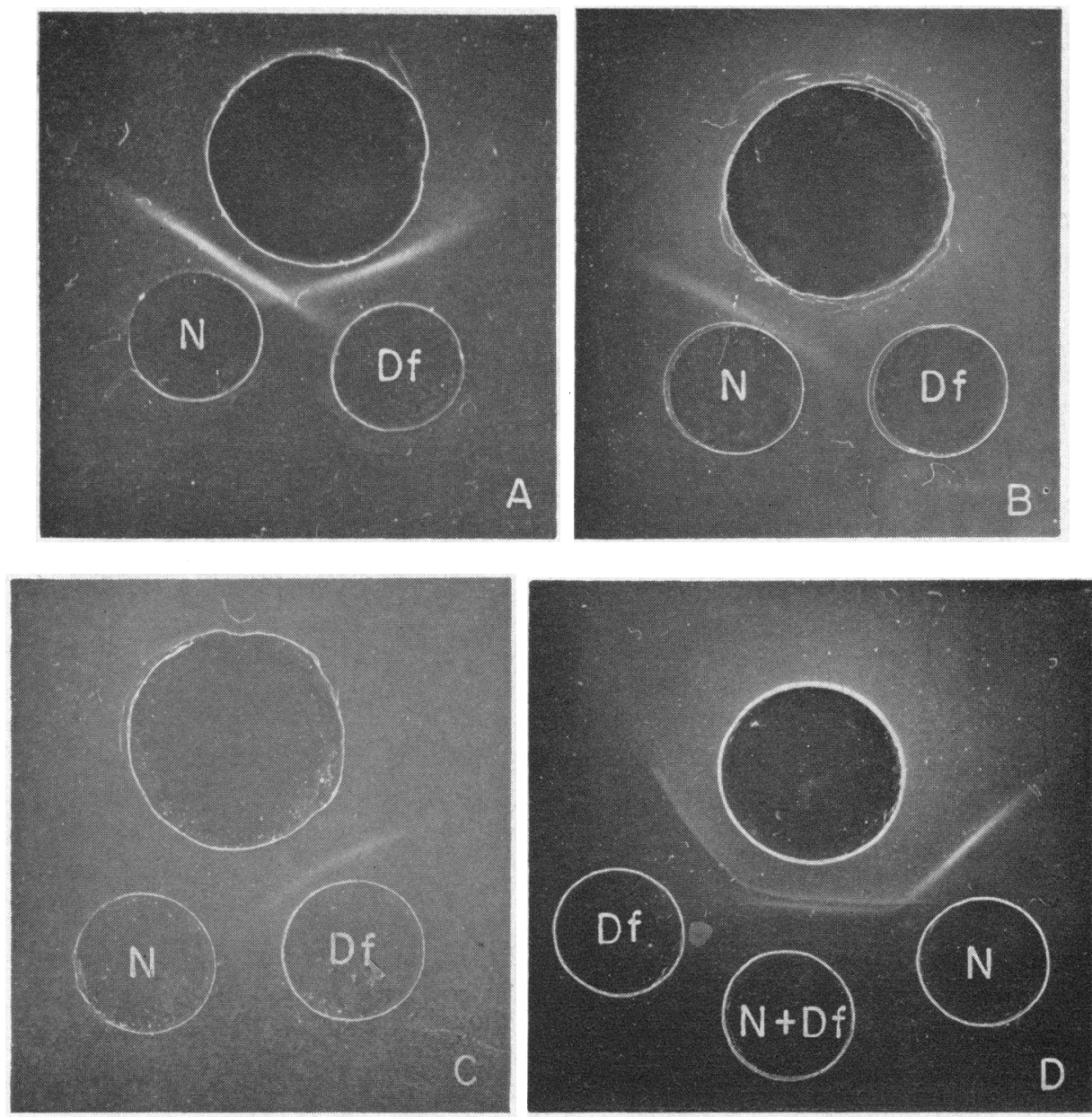

Fig. 14. SERUM 5443. (A) The reaction of unabsorbed serum shows double spurs. Upper well: serum 5443; left well: native DNA, $80 \mu \mathrm{g} / \mathrm{ml}$; right well: DNA denatured in the presence of formaldehyde, $50 \mu \mathrm{g} / \mathrm{ml}$. (B-C) Upper well: serum absorbed at equivalence by DNA denatured in the presence of formaldehyde (B) or by native DNA (C). Left well: native DNA, $25 \mu \mathrm{g} / \mathrm{ml}$. Right well: DNA denatured in the presence of formaldehyde, 15 $u \mathrm{~g} / \mathrm{ml}$. (D) Upper well: untreated serum; left well: DNA denatured in the presence of formaldehyde, $40 \mu \mathrm{g} / \mathrm{ml}$; bottom well : mixtures of native and denatured DNA, $30 \mu \mathrm{g}$ of each per ml. Right well: native DNA, $50 \mu \mathrm{g} / \mathrm{ml}$.

DNA line over denatured. After absorption with denatured DNA at equivalence, these sera still react with native DNA. However, in all instances, the addition of a great excess of pure denatured DNA resulted in negative reactions with native DNA. Inversely, with a few other sera, denatured DNA spurred over native DNA.

Finally, a single serum, showing precipitin lines with native and denatured DNA crossing each other with a decrease in intensity (Fig. 14A), has been studied in detail. This pattern suggested that this serum contained antibodies reacting with anti- genic determinants common to native and denatured DNA and with determinants specific for each of these forms. Absorption of this serum with denatured DNA at equivalence proves the existence of antibodies reacting only with native DNA (Fig. 14B). On the other hand, after absorption with native DNA at equivalence, this serum still reacts with denatured DNA (Fig. 14C). Furthermore, Fig. 14D shows that serum 5443 gives two distinct precipitin lines with a mixture of native and denatured DNA. The line closest to the antigen well is in identity with the 
native DNA line on the right, whereas the distal line is in identity with the denatured DNA line (left well); this line decreases in intensity after crossing the native DNA line. This is consistent with the hypothesis of antibodies reacting with antigenic determinants common to both forms of DNA. This was directly demonstrated by the study of purified antibodies obtained from a precipitate formed at equivalence with native DNA, since these antibodies reacted with both native and denatured DNA; moreover, the line of native DNA spurred over denatured DNA and the supernatant reacted exclusively with denatured DNA. The simultaneous occurrence of at least three kinds of DNA antibodies in this serum could be demonstrated in a single plate depicted in Fig. 15.

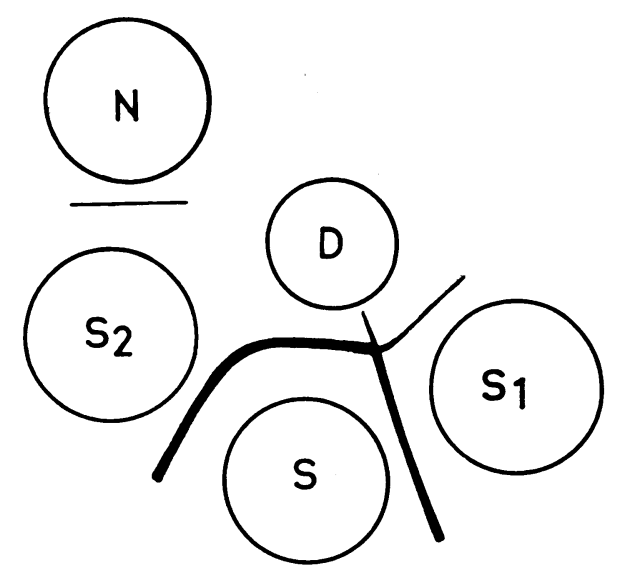

Fig. 15. Demonstration of the simultaneous occurRENCE OF THREE DIFFERENT KINDS OF ANTIBODIES IN SERUM 5443. S, untreated serum; $S 1$, supernatant 1 ; $S 2$, supernatant $2 ; D$, DNA denatured in the presence of formaldehyde; $N$, native DNA. For this experiment, one sample of serum was absorbed with native DNA at equivalence and a small excess of native DNA was then added (supernatant 1); another serum sample was absorbed with denatured DNA at equivalence and a small excess of denatured DNA was then added (supernatant $2)$. Both supernatants contain free antibodies and antigen excess. Supernatant 1 reacts at the same time with denatured DNA and with the antibodies to native DNA of the untreated serum. Supernatant 2 reacts at the same time with antibodies to denatured DNA of the untreated serum and with native DNA. Furthermore, the line of native DNA (between serum and supernatant 1) clearly decreases in intensity after crossing the denatured DNA line. This line with denatured DNA is weaker with supernatant 1 than with whole serum, because of the previous absorption of antibodies reacting with determinants common to both forms of DNA.

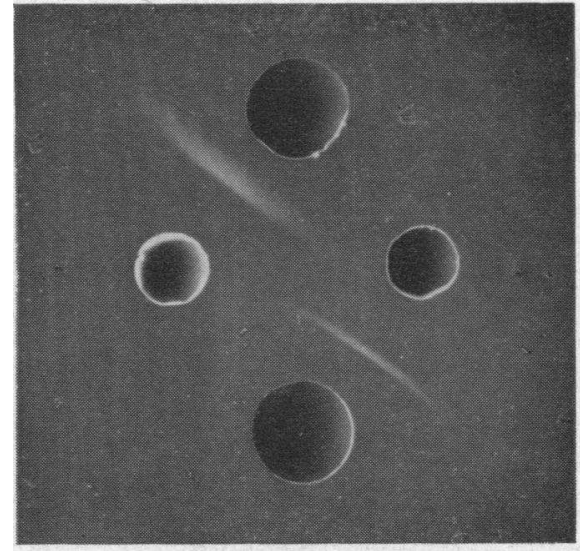

Fig. 16. IMmUNoglobulin ClASSES OF PURIFIEd ANTIBODIES To DNA. Upper well: purified antibodies from serum 12271; bottom: purified antibodies from serum 6969; left: rabbit antiserum to human IgG; right: rabbit antiserum to human IgM.

Immunoglobulin classes of purified antibodies. Anti-DNA antibodies were purified from four sera. Two sera, one precipitating only with native DNA and the other only with denatured DNA, contained antibodies of the IgG globulin class exclusively (Fig. 16, upper well). For another serum, antibodies reacting with antigenic determinants common to native and denatured DNA were purified. They were shown to belong to the IgM globulin class (Fig. 16, bottom well).

Purified antibodies from serum 5443 obtained from a precipitate formed at equivalence with native DNA showed to be of both IgG and IgM classes. To investigate their specificity further, double diffusion tests were performed in agarose, in which rabbit antiserum specific for $\gamma$ - or $\mu$ chains was included, as for single radial immunodiffusion tests (14). When anti-IgG globulin serum was included in the agarose, precipitin lines developed outside the ring, with both native and denatured DNA; this reaction was presumably due to $\operatorname{IgM}$ antibodies. On the other hand, when anti-IgM serum was included a reaction, presumably due to the IgG antibodies, occurred only with native DNA.

Purified antibodies were also tested against rabbit antisera to Bence Jones proteins, specific for each type of light chains. All the tested antibodies were of both $\mathrm{K}$ and $\mathrm{L}$ types; in one instance, type $\mathrm{L}$ molecules were predominant. 


\section{Discussion}

The present report demonstrates that, in at least 22 or 35 lupus sera studied, the anti-DNA antibodies react with native DNA, independently of denatured contaminants.

With certain sera, peak complement fixation was obtained with a concentration of native DNA manyfold greater than that required for denatured DNA. This type of pattern highly suggested that this reaction was due to a small amount of denatured DNA contaminating the native preparation. In most previous studies, similar reactions have been interpreted in this way. Use of native DNA purified by chromatography on columns of Kieselguhr impregnated with methylated albumin has proved to be of great value for this study, since this procedure allows the separation of native from denatured DNA. The usefulness of this purified native DNA is readily demonstrated by the experiments shown in Fig. 2. Thus, even when a concentration of native DNA up to a 100 -fold that of denatured DNA is needed for maximal complement fixation, it is impossible to conclude without further investigation that a contaminant is involved. In addition, it is interesting to note that not all antisera with antibodies to denatured DNA react with the denatured contaminant in this preparation before purification. These variations possibly reflect the different specificities of these antibodies.

The present studies indicate that, by complement fixation as well as by double diffusion tests, SLE sera show a broad range of relative reactivity with native and denatured DNA. This is reflected in complement fixation curves by exclusive, preferential, or identical reactions with native and/or denatured DNA, as judged by amount of complement fixed and antigen concentration at peak fixation. In double diffusion tests, similar variability can be demonstrated: in some instances, precipitin lines are seen only with native or denatured DNA, whereas other sera give identity or partial identity reactions.

The SLE sera used in this study contain three main types of DNA antibodies: those reacting only with denatured DNA, those reacting to the same extent with both forms of DNA, and those reacting preferentially with native DNA.
The first type of antibodies reacts with determinants hidden in the native molecule, as confirmed by the absence of inhibition by purified native DNA. Stollar et al. have extensively studied this type of antibodies. They have shown that these antibodies differ in specificity and, for some of them, they have identified the nature of the antigenic determinant on DNA $(15,16)$. As these authors observed, the denatured end products of DNAase digests were effective inhibitors. In our series, denatured RNA did not inhibit these antibodies to denatured DNA. With other lupus sera, denatured RNA was shown to inhibit only those antibodies reacting with purine bases (16). Such antibodies react with high concentrations of denatured DNA which, because of the anticomplementary activity of our preparation, were not used in this study.

The second type of antibodies reacts with antigenic determinants common to both forms of DNA. This is reflected by identical complement fixation curves or by reaction of identity in precipitin tests. Similar patterns have been described by others with occasional lupus sera $(9,17)$. Cross-inhibition studies in complement fixation and cross-absorption experiments in the precipitin system prove that the same antibodies react with both forms of DNA, presumably with "backbone" determinants. Since native and denatured RNA do not inhibit the reaction, deoxyribose might be involved in the antigenic site(s). The lack of inhibition by DNAse digests could reflect the requirement of larger oligonucleotide fractions. However, these inhibition studies were not performed for the two sera in this group which reacted maximally in complement fixation with relatively large amounts of DNA (approximately 1 $\mu \mathrm{g})$; this type of complement fixation curve suggests that these antibodies could react with a relatively small repeating determinant unit.

The third type of DNA antibodies reacts preferentially with native DNA. Several sera in this series react more strongly with native than with denatured DNA in complement fixation. Similarly, in double diffusion technique a definite spur of native over denatured DNA has been observed in several instances. Others have recently reported the occurrence of an analogous precipitin pattern (17) and a single similar reaction in complement fixation (18). One particular serum re- 
acts exclusively with native DNA in complement fixation and precipitin tests (19). Another, with no complement fixation data because of high anticomplementary activity, gives similar precipitin reactions in liquid and in gel. Such findings have not been previously reported either with SLE sera or with experimentally induced antibodies which react with DNA. They are of great interest because they point to the importance of conformation in the antigenic structure of DNA. The role of conformational structure in antigenic specificity has been recognized for several proteins (20), immunoglobulins (21-24), carbohydrate antigens (25), and it could also play a role in specificity of oligonucleotides and nucleotides $(25,26)$. However, it should be emphasized that the present experiments demonstrate that denatured DNA is a potential inhibitor of these antibodies to native DNA. Similarly, denatured DNA without detectable double chain areas was able to inhibit the antibodies responsible for the spurs of native over denatured DNA described in this study. It thus appears that the antigenic sites are presumably present on each chain of the DNA molecule, despite the inability to detect them by precipitin and complement fixation techniques. Positive reactions might be obtained upon recombination of the chains. The firm binding of these antibodies may require the rigid double helix structure of the native DNA. It should be noted that neither DNAse digests nor native RNA were able to inhibit the reaction. Variations in the degree of reactivity with native DNA samples from different sources have been observed (Fig. 8). Similar findings have been reported by Stollar et al. (9) for antibodies to denatured DNA and have been ascribed to variable extents of single strand areas in the preparations (27). This explanation is unlikely in our experiments with antibodies reacting preferentially with native DNA. There seems to be no correlation between the degree of reactivity and the molecular weight. The clarification of this point requires a thorough study of a much larger series of DNA samples.

The experiments with DNA upon renaturation (illustrated in Fig. 9) readily demonstrate the three main types of DNA antibodies described above.

The current study has shown the simultaneous occurrence of two of these different varieties of
anti-DNA antibodies in several SLE sera. All three kinds of antibodies can be present in a single serum sample. This latter possibility was demonstrated for serum 5443 by double diffusion in gel and absorption experiments (Figs. 14, 15). One might recall that the complement fixation pattern of this particular serum (Fig. $4 b$ ) was analogous to those of serum 3258 and 11752 . In the former (Fig. $4 a$ ), the same antibody was shown to react with native and denatured DNA. In the latter (Fig. 5), additional experiments showed that we were dealing with at least two different antibodies, either with different specificities or with different sizes of their antibody-combining sites, as described for antidextran antibodies (28).

The occurrence of several DNA antibodies in a single serum is possibly not infrequent. It should be emphasized that, in many instances, no definite conclusions in this regard can be drawn from the mere complement fixation curves. Thus, the interpretation of patterns similar to that of Fig. 3 is impossible in the absence of additional experiments: such reactions might be due either to the same antibody reacting with nonhelical regions of the native preparation or to two antibodies with different specificities. In addition, it should be remembered that the micro-complement fixation technique uses diluted antiserum and that the results reflect only the reaction(s) given by the most concentrated population(s) of antibodies. For example, serum 6969 gave identical complement fixation curves with native and denatured DNA, although precipitin studies showed a definite spur of native over denatured DNA (Fig. 13C). Moreover, antibodies reacting preferentially with native DNA or with antigenic determinants common to native and denatured DNA might in some instances escape detection, since the presence of native DNA in the serum of some patients with SLE has been demonstrated recently (17).

The present work shows that anti-DNA antibodies from different SLE patients as well as from a single patient vary greatly with respect to the specificity of their receptor sites. This broad heterogeneity probably explains the discrepancies between some of our early results and those of others (29).

Although a limited number of purified antibodies were tested, it was shown that human anti-DNA 
antibodies can belong to the $\operatorname{IgM}$ globulin class. This finding is in contrast with the recent data of Stollar and Sandberg (18) and with earlier observations from this (5) and other (6) laboratories. In all these instances, anti-DNA antibodies were shown to be $\operatorname{IgG}$ globulins. However, antinuclear antibodies detected by immunofluorescent techniques have been found in all three immunoglobulin classes $(30,31)$. The present study of one serum containing both IgG and IgM antiDNA antibodies demonstrated that different specificities could be assigned to each immunoglobulin class. The finding that purified anti-DNA antibodies contain molecules with both types of light chains is not unexpected, since we are dealing with heterogeneous system.

Antibodies to denatured DNA have been applied with success to biochemical and physicochemical studies (32-34). A promising list of potential applications to biological problems has been recently drawn up (35). Similarly antibodies from SLE patients reacting preferentially or only with native DNA, as described in this report, might prove valuable in many respects and especially for conformational studies. As we have noted, the antigenic activity of renatured DNA is similar to but not identical with that of native DNA. Furthermore, preliminary experiments suggest that anti-native DNA antibodies are able to distinguish the double chain helix of DNA from the configuration of a DNA-RNA hybrid.

In contrast to the present findings with antiDNA antibodies from SLE patients, most of the experimentally produced antibodies capable of reacting with DNA react only with denatured DNA. These negative reactions with native DNA are expected for the antibodies elicited by immunization with purines and pyrimidines coupled to proteins (36-39) or to synthetic polypeptides (40). The paradoxical finding of positive reactions of some anti-5-acetyl-uracyl antibodies with native DNA (37) remains unexplained. However, it should be noted that no antibodies reacting to the same extent with native and denatured DNA have been detected in the serum of animals immunized with denatured DNA or polynucleotides complexed with methylated bovine serum albumin $(41,42)$, with T-even bacteriophage lysates (10) or with Gram-negative bacteria (43). The proper immunization procedure for producing antibodies re- acting equally or preferentially with native DNA has possibly not yet been devised. Preliminary results, reported by Beiser and Erlanger (35), indicate that native calf thymus DNA is immunogenic in rabbits previously immunized with DNAse. However, these antibodies also react only with denatured DNA. Thus, at the present time, no experimental model is available for the broad spectrum of anti-DNA antibodies in SLE. Therefore, the various types of experimentally induced antibodies do not help us to understand the mechanisms involved in the production of DNA antibodies in SLE whose presence is associated with the acute stages of the disease (5).

\section{Acknowledgments}

We are grateful to Dr. Elvin Kabat for reviewing the English manuscript. We wish to thank Dr. C. J. Larsen for Kieselguhr chromatography, Doctors F. Gros and R. Van Rapenbusch for gifts of DNA preparations, Dr. J. M. Dubert for supplying the DNA-RNA hybrid, and Dr. L. Levine for teaching Dr. Arana his quantitative complement fixation technique. The skillful technical assistance of Miss A. Chevalier is also gratefully acknowledged.

\section{References}

1. Seligmann, M. 1957. Mise en évidence dans le sérum de malades atteints de lupus érythémateux disséminé d'une substance déterminant une réaction de précipitation avec l'acide désoxyribonucléique. Compt. Rend. 245 : 243.

2. Robbins, W. C., H. R. Holman, H. Deicher, and H. G. Kunkel. 1957. Complement fixation with cell nuclei and DNA in lupus erythematosus. Proc. Soc. Exptl. Biol. Med. 96: 575.

3. Ceppellini, R., E. Polli, and F. Celada. 1957. A DNA reacting factor in serum of a patient with lupus erythematosus diffusus. Proc. Soc. Exptl. Biol. Med. 96 : 572.

4. Seligmann, M., and F. Milgrom. 1957. Mise en évidence par la fixation du complément de la réaction entre acide désoxyribonucléique et le sérum de malades atteints de lupus érythémateux disséminé. Compte. Rend, 245 : 1472.

5. Seligmann, M. 1958. Etudes immunologiques sur le lupus érythémateux disséminé. Rev. Franc. Etudes Clin. Biol. 3: 558.

6. Deicher, H. R. G., H. R. Holman, and H. G. Kunkel. 1959. The precipitin reaction between DNA and a serum factor in systemic lupus erythematosus. $J$. Exptl. Med. 109 : 97.

7. Barbu, E., M. Seligmann, and M. Joly. 1960. Réactions entre des acides désoxyribonucléiques di- 
versement dénaturés ou dégradés et les anticorps anti-acide désoxyribonucléique du sérum de malades atteints de lupus érythémateux disséminé. Ann. Inst. Pasteur. 99 : 695.

8. Stollar, D., and L. Levine. 1961. Antibodies to denatured deoxyribonucleic acid in a lupus erythematosus serum. J. Immunol. 87: 477.

9. Stollar, D., L. Levine, and J. Marmur. 1962. Antibodies to denatured deoxyribonucleic acid in lupus erythematosus serum. II. Characterization of antibodies in several sera. Biochim. Biophys. Acta. 61 : 7.

10. Levine, L., W. T. Murakami, H. Van Vunakis, and L. Grossmann. 1961. Specific antibodies to thermally denatured deoxyribonucleic acid of phage T4. Proc. Natl. Acad. Sci. 46 : 1038.

11. Mandel, J. D., and A. D. Hershey. 1960. A fractionating column for analysis of nucleic acids. Anal. Biochem. $1: 66$.

12. Prudhomme, R. O., and P. Grabar. 1947. Etude de la dénaturation des protéides. I. Action des ultrasons sur les protéides du sérum de cheval normal et sur les acides aminés cycliques. Bull. Soc. Chim. Biol. 29 : 122.

13. Wasserman, E., and L. Levine. 1961. Quantitative micro-complement fixation and its use in the study of antigenic structure by specific antigen-antibody inhibition. J. Immunol. $87: 290$.

14. Mancini, G., A. O. Carbonara, and J. F. Heremans. 1965. Immunochemical quantitation of antigens by single radial immunodiffusion. Immunochemistry. $2: 235$.

15. Stollar, D., L. Levine, H. I. Lehrer, and H. Van Vunakis. 1962. The antigenic determinants of denatured DNA reactive with lupus erythematosus serum. Proc. Natl. Acad. Sci. $48: 874$.

16. Stollar, D., and L. Levine. 1963. Antibodies to denatured deoxyribonucleic acid in lupus erythematosus serum. IV. Evidence for purine determinants in DNA. Arch. Biochem. Biophys. 101: 417.

17. Tan, E. M., P. H. Schur, R. I. Carr, and H. G. Kunkel. 1966. Deoxyribonucleic acid (DNA) and antibodies to DNA in the serum of patients with systemic lupus erythematosus. J. Clin. Invest. 45 : 1732.

18. Stollar, B. D., and A. L. Sandberg. 1966. Comparisons of antibodies reacting with DNA. I. Systemic lupus erythematosus sera and rabbit antibodies induced by DNA-methylated bovine serum albumin complexes. J. Immunol. 96: 755.

19. Arana, R., and M. Seligmann. 1966. Présence, dans certains sérums de lupus, d'anticorps anti-acide désoxyribonucléique natif. Compt. Rend. 262: 2665.

20. Haber, E., J. C. Bennett, and J. A. Mills. 1964. The relationship of the three dimensional conformation of proteins to their antigenic specificity. Medicine. $43: 305$.
21. Polmar, S. H., and A. G. Steinberg. 1964. Dependence of a $\mathrm{Gm}$ (b) antigen on the quaternary structure of human gamma globulin. Science. 145: 928.

22. Gold, E. R., W. J. Mandy, and H. H. Fudenberg. 1965. Relation between $\mathrm{Gm}(\mathrm{f})$ and the structure of the gamma-globulin molecule. Nature. 207: 1099.

23. Seligmann, M., C. Mihaesco, and G. Meshaka. 1966. Antigenic determinants common to human immunoglobulins $\mathrm{G}$ and $\mathrm{M}$ : importance of conformational antigens. Science. $154: 790$.

24. Prendergast, R. A., H. M. Grey, and H. G. Kunkel. 1966. Recombination of heavy and light chains of human gamma A-myeloma proteins: Formation of hybrid molecules and configurational specificity. J. Exptl. Med. 124 : 185.

25. Kabat, E. A. 1966. The nature of an antigenic determinant. J. Immunol. 97: 1 .

26. Vournakis, J. N., H. A. Scheraga, G. W. Rushizky, and H. A. Sober. 1966. Neighbor-Neighbor interactions in single-strand polynucleotides: Optical rotatory dispersion studies of the ribonucleotide ApApCp. Biopolymers. $4: 33$.

27. Levine, L. 1963. Discussion in DNA antibodies. Arthritis Rheumat. 6: 547.

28. Gelzer, J., and E. A. Kabat. 1964. Specific fractionation of human antidextran antibodies. II. Assay of human antidextran sera and specifically fractionated purified antibodies by microcomplement fixation and complement fixation inhibition techniques. J. Exptl. Med. 119 : 983.

29. Seligmann, M. 1963. Discussion in DNA antibodies. Arthritis Rheumat. 6: 542.

30. Barnett, E. V., J. J. Condemi, J. P. Leddy, and J. H. Vaughan. 1964. Gamma 2 , Gamma 14 and Gamma 1 s antinuclear factors in human sera. J. Clin. Invest. $43: 1104$.

31. Holborow, E. J., and G. D. Johnson. 1965. The nature of antinuclear immunoglobulins. Ann. N. Y. Acad. Sci. $124: 833$.

32. Stollar, D., and L. Grossman. 1962. The reaction of formaldehyde with denatured DNA: Spectrophotometric, immunologic, and enzymic studies. J. Mol. Biol. 4 : 31 .

33. Stollar, D., and L. Levine. 1963. Antibodies to denatured deoxyribonucleic acid in lupus erythematosus serum. V. Mechanism of DNA-anti-DNA inhibition by chloroquine. Arch. Biochem. Biophys. 101 : 335.

34. Seaman, E., L. Levine, and H. Van Vunakis. 1966. Antibodies to the methylene blue sensitized photooxidation product in deoxyribonucleic acid. Biochemistry. 5 : 1216.

35. Beiser, S. M., and B. F. Erlanger. 1966. Antibodies which react with nucleic acids. Cancer Res. 26: 2012.

36. Butler, V. P., S. M. Beiser, B. F. Erlanger, S. W. Tanenbaum, S. Cohen, and A. Bendich. 1962. Purine-specific antibodies which react with deoxyri- 
bonucleic acid (DNA). Proc. Natl. Acad. Sci. 48 : 1597.

37. Tanenbaum, S. W., and S. M. Beiser. 1963. Pyrimidine-specific antibodies which react with deoxyribonucleic acid (DNA). Proc. Natl. Acad. Sci. $49: 662$.

38. Beiser, S. M., S. W. Tanenbaum, and B. F. Erlanger. 1964. Purine- and pyrimidine-specific antibodies: Precipitation with denatured deoxyribonucleic acid. Nature. 203 : 1381.

39. Erlanger, B. F., and S. M. Beiser. 1964. Antibodies specific for ribonucleosides and ribonucleotides and their reaction with DNA. Proc. Natl. Acad. Sci. 52: 68.
40. Sela, M., H. Ungar-Waron, and Y. Shechter. 1964. Uridine-specific antibodies obtained with synthetic antigens. Proc. Natl. Acad. Sci. 52: 285.

41. Plesca, O. J., W. Braun, and N. C. Palczuk. 1964. Production of antibodies to denatured deoxyribonucleic acid (DNA). Proc. Natl. Acad. Sci. 52: 279.

42. Plesca, O. J., N. C. Palczuk, W. Braun, and E. Cora-Figueroa. 1965. Antibodies to DNA and a synthetic polydeoxyribonucleotide produced by oligodeoxyribonucleotides. Science. 148: 1102.

43. Christian, C. L., A. R. Desimone, and J. L. Abruzzo. 1965. Anti-DNA antibodies in hyperimmunized rabbits. J. Exptl. Med. $121: 309$. 